\title{
Aminosilicones without Protecting Groups: Using
}

\section{Natural Amines}

\author{
Adrien Lusterio, Miguel Melendez-Zamudio and Michael A. Brook*
}

Department of Chemistry and Chemical Biology, McMaster University, 1280 Main St. W., Hamilton ON Canada L8S 4M1.

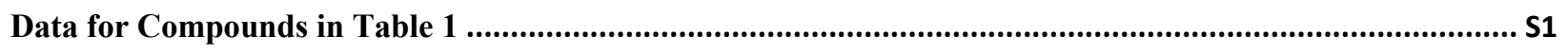

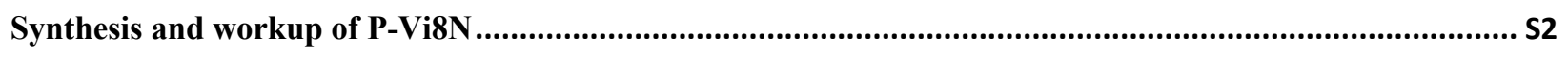

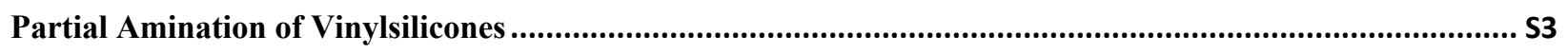

Attempted Hydrosilylation of Amino Sulfide Silicones ............................................................................ S5

Conversion of Amino Sulfide Silicones into other Materials ....................................................................... S7

\section{Data for Compounds in Table 1}

M2N: ${ }^{1} \mathrm{H}-\mathrm{NMR}\left(\mathrm{CDCl}_{3}, 600 \mathrm{MHz}\right): \delta 2.84(\mathrm{t}, 2 \mathrm{H}, J=6.2 \mathrm{~Hz}), 2.60-2.54(\mathrm{~m}, 4 \mathrm{H}$, overlapping),

1.51 (s, $2 \mathrm{H}$, broad, $\mathrm{NH}_{2}$ protons), 0.88-0.83 (m, 2H), 0.07-0.03 (m, 45H). ${ }^{13} \mathrm{C}-\mathrm{NMR}\left(\mathrm{CDCl}_{3}, 150\right.$ MHz): $\delta 41.23,36.26,26.45,15.73,1.92,1.20 \mathrm{ppm}$. GCMS EI $\left[\mathrm{M}-\mathrm{CH}_{3}\right]^{+}$at m/z 606.2.

M3N: ${ }^{1} \mathrm{H}-\mathrm{NMR}\left(\mathrm{CDCl}_{3}, 600 \mathrm{MHz}\right): \delta 2.86(\mathrm{t}, 2 \mathrm{H}, J=6.4 \mathrm{~Hz}), 2.62-2.59$ (m, 4H, overlapping), $1.75\left(\mathrm{~s}, 2 \mathrm{H}\right.$, broad, $\mathrm{NH}_{2}$ protons $), 0.91-0.88(\mathrm{~m}, 2 \mathrm{H}), 0.09-0.04(\mathrm{~m}, 63 \mathrm{H}) \mathrm{ppm} .{ }^{13} \mathrm{C}-\mathrm{NMR}\left(\mathrm{CDCl}_{3}\right.$, $150 \mathrm{MHz}): \delta 41.30,36.35,26.44,15.71,1.88,-1.92$. ESI $[\mathrm{M}+\mathrm{H}]^{+}$at $\mathrm{m} / \mathrm{z} 844.3$. 
M4: ${ }^{1} \mathrm{H}-\mathrm{NMR}\left(\mathrm{CDCl}_{3}, 600 \mathrm{MHz}\right): \delta 6.01(\mathrm{dd}, 1 \mathrm{H}, J=14.9,19.7 \mathrm{~Hz}), 5.93(\mathrm{dd}, 1 \mathrm{H}, J=14.9,4.6$ $\mathrm{Hz}), 5.80(\mathrm{dd}, 1 \mathrm{H}, J=19.8,4.6 \mathrm{~Hz}), 1.33-1.30(\mathrm{~m}, 8 \mathrm{H}$, overlapping $), 0.89(\mathrm{t}, 6 \mathrm{H}, J=6.9 \mathrm{~Hz}), 0.54$ $(\mathrm{t}, 4 \mathrm{H}, J=9.2 \mathrm{~Hz}), 0.09-0.05(\mathrm{~m}, 204 \mathrm{H}) \mathrm{ppm}$.

M4N: ${ }^{1} \mathrm{H}-\mathrm{NMR}\left(\mathrm{CDCl}_{3}, 600 \mathrm{MHz}\right): \delta 2.86(\mathrm{t}, 2 \mathrm{H}, J=6.1 \mathrm{~Hz}), 2.62(\mathrm{t}, 2 \mathrm{H}, J=6.2 \mathrm{~Hz}), 2.57(\mathrm{t}$, $2 \mathrm{H}, J=8.9 \mathrm{~Hz}), 1.49\left(\mathrm{~s}, 2 \mathrm{H}\right.$, broad, $\mathrm{NH}_{2}$ protons), 1.33-1.31 (m, 8H, overlapping), 0.89-0.86 (m, $8 \mathrm{H}$, overlapping), $0.53(\mathrm{t}, 4 \mathrm{H}, J=9 \mathrm{~Hz}), 0.08-0.04\left(\mathrm{~m}, 204 \mathrm{H}\right.$, overlapping), ppm. ${ }^{13} \mathrm{C}-\mathrm{NMR}$ $\left(\mathrm{CDCl}_{3}, 150 \mathrm{MHz}\right): \mathrm{d} 0.32,1.19,13.95,18.12,18.66,25.62,26.42,26.53,36.30,41.25 \mathrm{ppm}$.

T-Vi8N: ${ }^{1} \mathrm{H}-\mathrm{NMR}\left(\mathrm{CDCl}_{3}, 600 \mathrm{MHz}\right): \delta 3.22(\mathrm{~m}, 4 \mathrm{H}), 2.98-2.91(\mathrm{~m}, 4 \mathrm{H}), 2.65-2.59(\mathrm{~m}, 4 \mathrm{H})$, 0.91-0.88 (m, 4H), 0.12-0.04 (m, 74H). ${ }^{13} \mathrm{C}-\mathrm{NMR}\left(\mathrm{CDCl}_{3}, 150 \mathrm{MHz}\right): \delta 0.43,1.16,18.86,26.86$, $28.93,39.24$.

T-Vi376N: ${ }^{1} \mathrm{H}-\mathrm{NMR}\left(\mathrm{CDCl}_{3}, 600 \mathrm{MHz}\right): \mathrm{d} 3.18(\mathrm{t}, \mathrm{J}=6.5 \mathrm{~Hz}, 4 \mathrm{H}), 2.89(\mathrm{t}, \mathrm{J}=6.5 \mathrm{~Hz}, 4 \mathrm{H}), 2.60$ $(\mathrm{t}, \mathrm{J}=8.5 \mathrm{~Hz}, 4 \mathrm{H}), 0.90(\mathrm{t}, \mathrm{J}=8.8 \mathrm{~Hz}), 0.09-0.06(\mathrm{~m}, 2536 \mathrm{H}$, overlapping $) .{ }^{13} \mathrm{C}-\mathrm{NMR}\left(\mathrm{CDCl}_{3}\right.$, $150 \mathrm{MHz}): \mathrm{d} 1.17,18.91,25.79,26.92,39.03$.

\section{Synthesis and workup of P-Vi8N}

To an oven dried round-bottom flask equipped with a stirrer was added cysteamine hydrochloride and a mixture of appropriate solvents (Table 1). After a complete dissolution of the salt, the pendent vinyl silicone was added; if the solution become foggy more of the solvent was added until clarity is reached, then the photoinitiator was added (DMPA). The flasks were covered with aluminum-foil, only exposing one side to the $365 \mathrm{~nm} \mathrm{UV} \mathrm{lamp} \mathrm{(100} \mathrm{watts,} 1.27 \mathrm{~W} / \mathrm{cm}^{2}$ ). For PVi8 $(7-8 \%), 2$ hours were necessary to complete the reaction with excess of cysteamine hydrochloride (2.0 eq.). At the end of the process a slightly yellow and transparent solution was obtained.

Triethylamine ( $0.97 \mathrm{~mL}, 7.023 \mathrm{mmol}$ ) was used to neutralize the $\mathrm{HCl}$ on cysteamine; for P-Vi8N the resulting viscous oil was dissolved in THF and triethylamine was added, the solution stirred overnight. The salt produced was removed by centrifugation (4000 rpm) and THF removed using 
rotatory evaporation. The copolymer was dissolved in DCM, washed with brine and dried over $\mathrm{Na}_{2} \mathrm{SO}_{4}$ and, after filtration, concentrated by rotatory evaporation and dried for $24 \mathrm{~h}$ over $\mathrm{N}_{2}$ flow.

P-Vi8N: ${ }^{1} \mathrm{H}-\mathrm{NMR}\left(\mathrm{CDCl}_{3}, 600 \mathrm{MHz}\right): \delta 3.76(\mathrm{~m}, 2 \mathrm{H}, \mathrm{NH} 2), 2.87(\mathrm{~m}, 2 \mathrm{H}, J=9.68 \mathrm{~Hz}), 2.58$

$(\mathrm{m}, 2 \mathrm{H}, J=9.08), 2.62(\mathrm{~m}, 2 \mathrm{H}, J=2.62), 0.87(\mathrm{~m}, 2 \mathrm{H}, J=8.48), 0.07(\mathrm{~m}, 50 \mathrm{H}) \mathrm{ppm} .{ }^{13} \mathrm{C}-\mathrm{NMR}$ $\left(\mathrm{CDCl}_{3}, 150 \mathrm{MHz}\right): \delta 41.06,36.02,26.26,18.48,1.08 .{ }^{29} \mathrm{Si}-\mathrm{NMR}\left(\mathrm{CDCl}_{3}, 119 \mathrm{MHz}\right): \delta$-21.94, 25.40. IR-ATR $\left(\mathrm{cm}^{-1}\right): 1599(\mathrm{~N}-\mathrm{H}, \delta)$.

\section{Partial Amination of Vinylsilicones}

To an oven dried round-bottomed flask equipped with a stirrer was added cysteamine hydrochloride (0.25 eq., $0.36 \mathrm{~g}, 3.16 \mathrm{mmol})$ in a 1:2 EtOH:THF (15 mL) (for polymers modified with 0.50 eq. and 0.75 eq., see Table S1). After complete dissolution of the salt (if the solution become foggy more of the solvent was added until clarity was reached) P-Vi50 (2.05 g, $12.8 \mathrm{mmol})$ and then the photoinitiator DMPA were added $(0.03 \mathrm{~g}, 0.12 \mathrm{mmol})$. The flasks were covered with aluminum-foil, only exposing one side to the $365 \mathrm{~nm}$ UV lamp (100 watts, $1.27 \mathrm{~W} / \mathrm{cm}^{2}$ ) for a period of $10 \mathrm{~min}$; a white viscous liquid that corresponds to the cysteamine chloride modified copolymer precipitated from the solution. The workup is described within the synthesis of $\mathbf{P}$ Vi50N. 


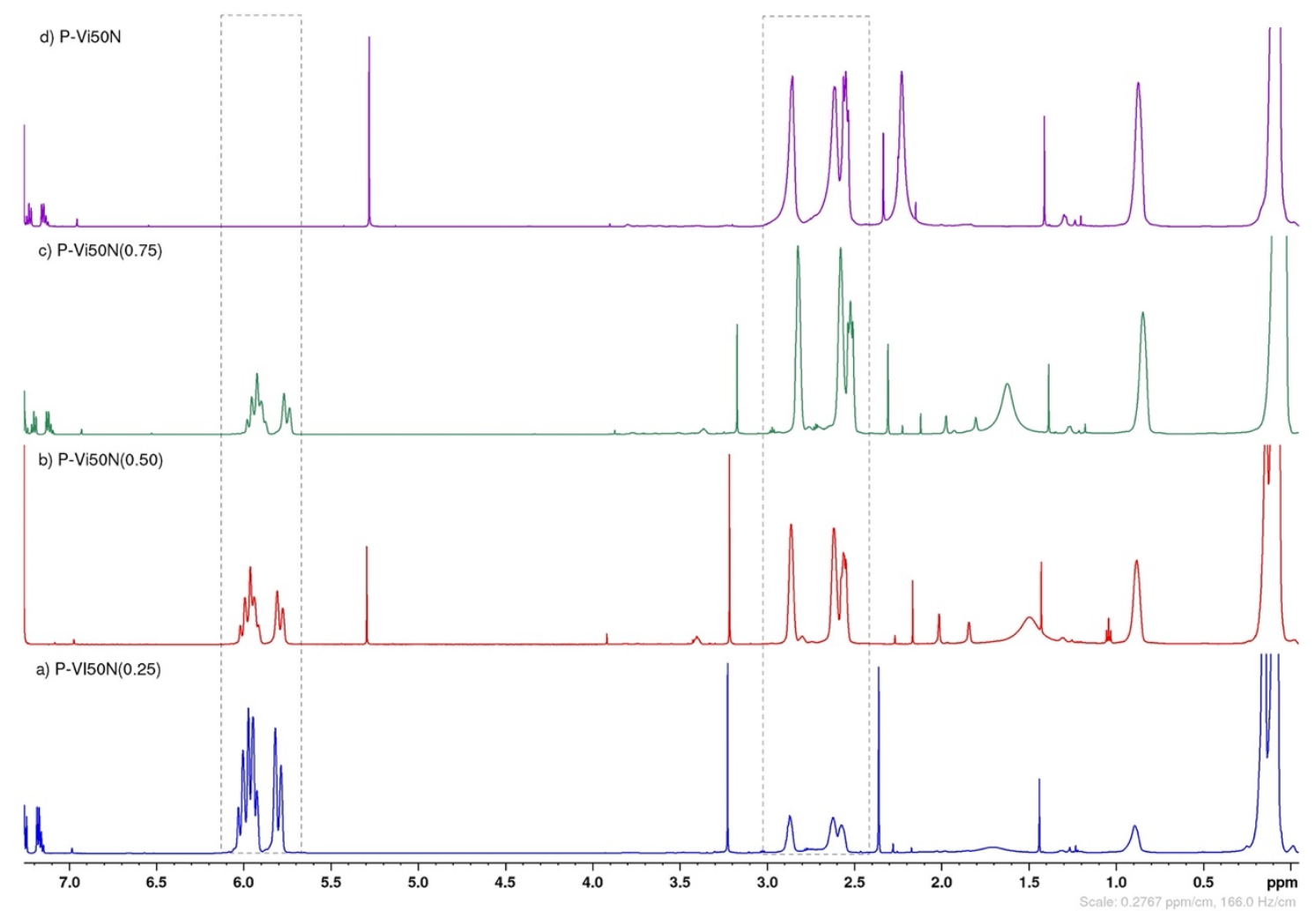

Figure S1. ${ }^{1} \mathrm{H}$ NMR of P-Vi50N reacted with different equivalents of cysteamine ( a) 0.25 eq., b) 0.50 eq., c) 0.75 eq. and d) 1.0 e.q.) in $\mathrm{CDCl}_{3}$.

P-Vi50N: ${ }^{1} \mathrm{H}-\mathrm{NMR}\left(\mathrm{CDCl}_{3}, 600 \mathrm{MHz}\right): \delta 6.02-5.77(\mathrm{~m}, 3.31 \mathrm{H}), 0.14-0.07(\mathrm{~m}, 10 \mathrm{H}) \mathrm{ppm}$.

P-Vi50N(0.25): ${ }^{1} \mathrm{H}-\mathrm{NMR}\left(\mathrm{CDCl}_{3}, 600 \mathrm{MHz}\right): \delta 6.02-5.78(\mathrm{~m}, 2.75 \mathrm{H}),, 2.87-2.56(\mathrm{~m}, 1.06$ $\mathrm{H}), 0.88(\mathrm{~m}, 0.35 \mathrm{H}), 0.14-0.07(\mathrm{~m}, 10 \mathrm{H}) \mathrm{ppm}$.

P-Vi50N(0.50): ${ }^{1} \mathrm{H}-\mathrm{NMR}\left(\mathrm{CDCl}_{3}, 600 \mathrm{MHz}\right): \delta 6.02-5.77(\mathrm{~m}, 1.59 \mathrm{H}), 2.86-2.54(\mathrm{~m}, 3.11$ $\mathrm{H}), 0.88(\mathrm{~m}, 1.05 \mathrm{H}), 0.14-0.07(\mathrm{~m}, 10 \mathrm{H}) \mathrm{ppm}$.

P-Vi50N(0.75): ${ }^{1} \mathrm{H}-\mathrm{NMR}\left(\mathrm{CDCl}_{3}, 600 \mathrm{MHz}\right): \delta 6.02-5.77(\mathrm{~m}, 1.07 \mathrm{H}), 2.87-2.53(\mathrm{~m}, 4.14$ $\mathrm{H}), 0.88(\mathrm{~m}, 1.38 \mathrm{H}), 0.09-0.07(\mathrm{~m}, 10 \mathrm{H}) \mathrm{ppm}$.

Table S1. Percentage of conversion for P-Vi50N modified with different equivalents of cysteamine.

\begin{tabular}{ccccc}
$\begin{array}{c}\text { Mass of vinyl- } \\
\text { silicone g }\end{array}$ & $\begin{array}{c}\text { Mass of } \\
\text { (mmol) }\end{array}$ & $\begin{array}{c}\text { Eq. of } \\
\text { (mPA g }\end{array}$ & $\begin{array}{c}\text { Cysteamine } \\
\text { Cysteamine-HCl g }\end{array}$ & $\begin{array}{c}\text { \% Conversion } \\
\text { a }\end{array}$ \\
\hline HCl & Hmol & $($ mmol $)$ &
\end{tabular}




$\begin{array}{llccc}2.05(12.8) & 0.03(0.12) & 0.25 & 0.36(3.16) & 16.3 \\ 2.00(12.5) & 0.03(0.12) & 0.50 & 0.71(6.24) & 51.9 \\ 2.03(12.6) & 0.03(0.12) & 0.75 & 1.06(9.33) & 67.6 \\ 4.03(25.1) & 0.06(0.25) & 1.0 & 3.27(28.78) & 100\end{array}$

aThe $\%$ conversion is based on the integration of the vinyl signals from the ${ }^{1} \mathrm{H}$ NMR of each sample.

\section{Attempted Hydrosilylation of Amino Sulfide Silicones}

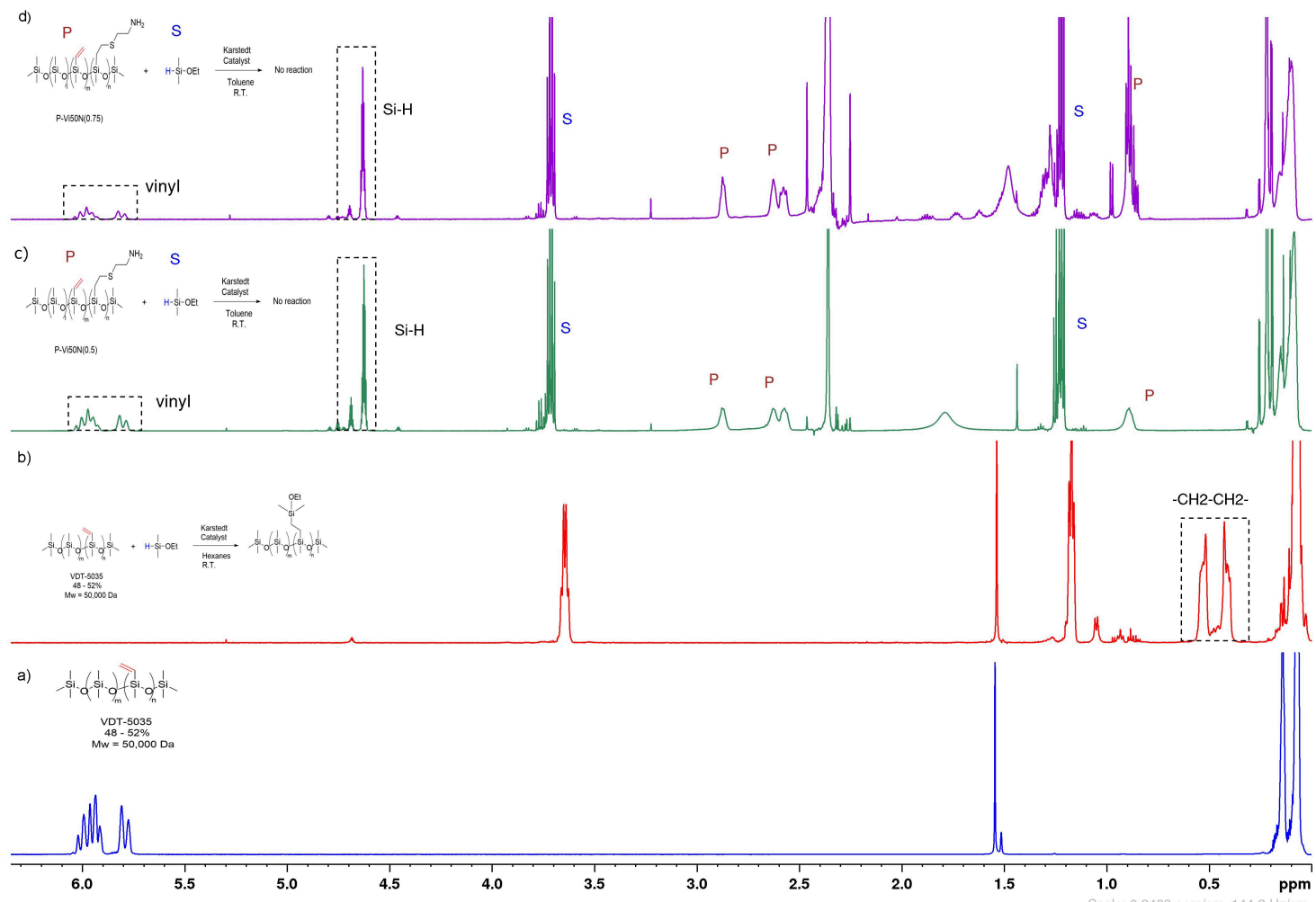

Figure S2. ${ }^{1} \mathrm{H}$ NMR for the hydrosilylation experiments of partially modified P-Vi50N: a) P-Vi50 (VDT-5035), b) hydrosilylation of P-Vi50 with $\mathrm{HSiMe}_{2} \mathrm{OEt}$ c) hydrosilylation of P-Vi50N(0.5) and d) hydrosilylation of $\mathbf{P}-\mathbf{V i 5 0 N}(\mathbf{0 . 7 5})$ in $\mathrm{CDCl}_{3}$. $\mathrm{P}=\mathrm{P}-\mathrm{Vi50N}(\mathrm{X}), \mathrm{S}=$ ethoxydimethylsilane 


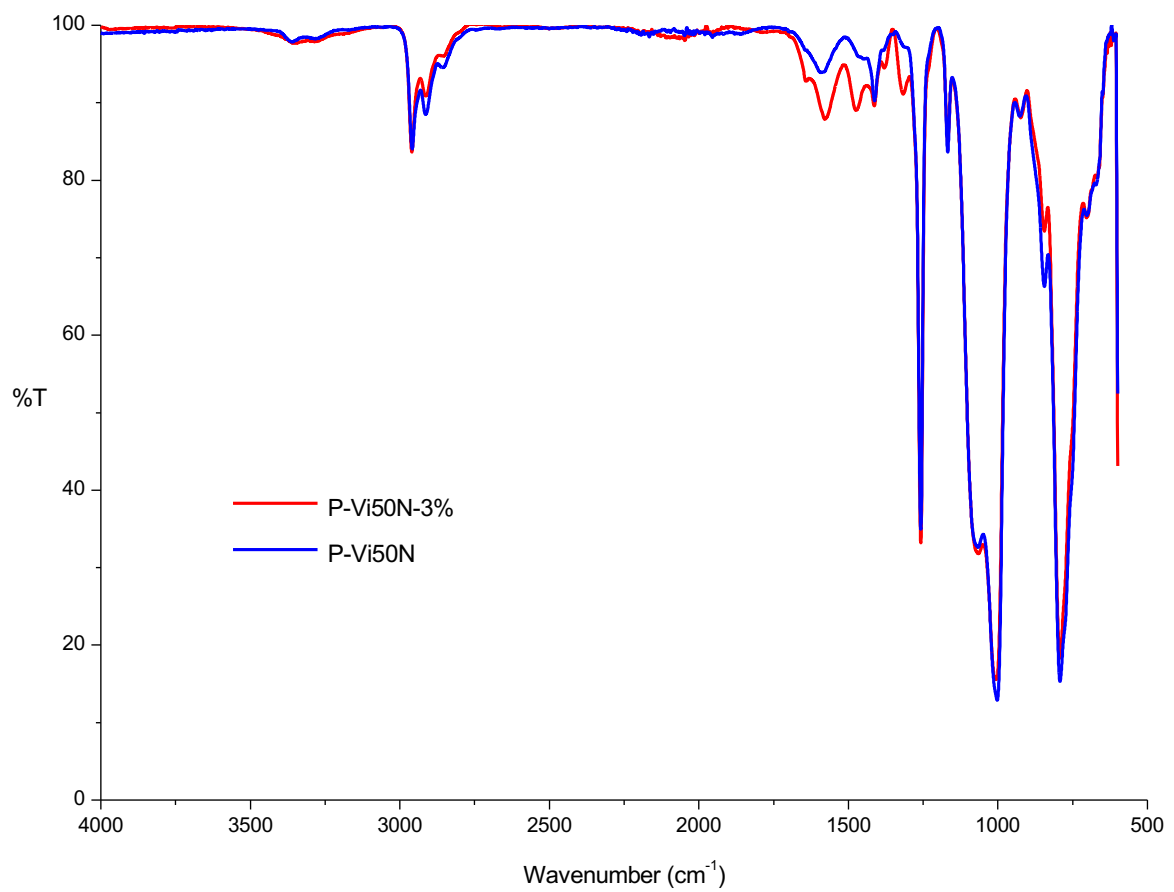

Figure S3. IR-ATR of P-Vi50N and P-Vi50N-3\%. 


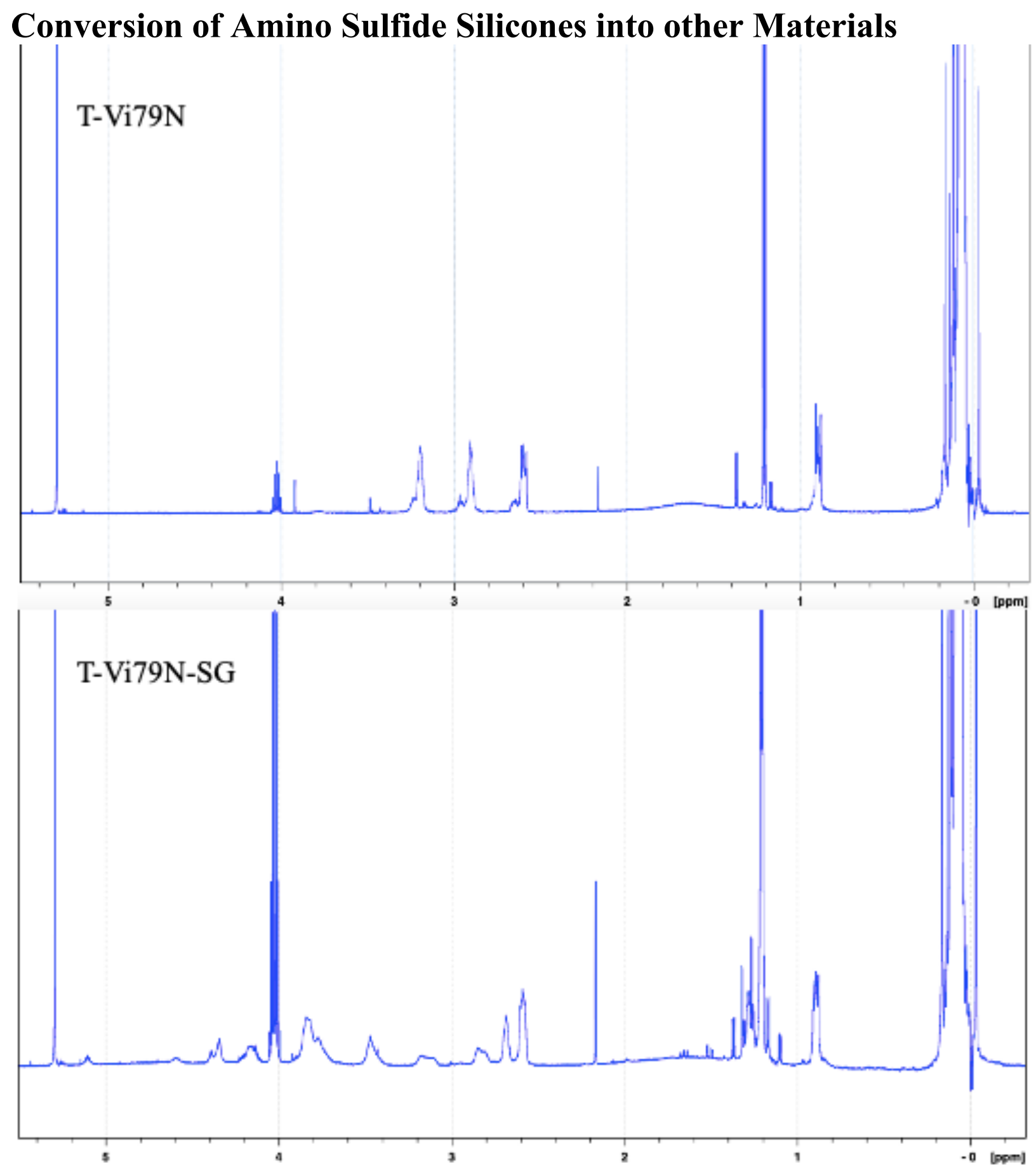

Figure S4. ${ }^{1} \mathrm{H}-\mathrm{NMR}$ spectra in $\mathrm{CDCl}_{3}$ of $\mathbf{T}-\mathbf{V i 7 9 N}$ (top), and after modification with gluconolactone resulting in T-Vi79N-SG (bottom). Once modified with the sugar, several peaks corresponding to glucose signals are observed in the 3-5 ppm range, along with shifts of the methylene signals adjacent to the nitrogen once the amide is formed from the amine. 
T-Vi79N-SG: ${ }^{1} \mathrm{H}-\mathrm{NMR}\left(\mathrm{CDCl}_{3}, 600 \mathrm{MHz}\right): \delta 0.05\left(\mathrm{Si}_{-} \mathrm{CH}_{3}\right), 0.89\left(4 \mathrm{H}, \mathrm{SiCH}_{2} \mathrm{CH}_{2} \mathrm{~S}\right), 2.59(4 \mathrm{H}$, $\mathrm{SiCH}_{2} \mathrm{CH}_{2} \mathrm{~S}$ ), 2.68-2.85 (4H, $\mathrm{SCH}_{2} \mathrm{CH}_{2} \mathrm{NH}$ ), 3.18 (2H, CH glucose), 3.47 (2H, CH glucose), 3.73$3.86\left(8 \mathrm{H}\right.$, overlapping $\mathrm{SCH}_{2} \mathrm{CH}_{2} \mathrm{NH}$ and $\mathrm{CH}_{2}$ (glucose) signals), 4.15 (2H, $\mathrm{CH}$ glucose), 4.33-4.40 (3H, CH glucose). FT-IR ( $\left.\left.\left.\mathrm{cm}^{-1}\right): 3374(v \mathrm{O}-\mathrm{H})\right), 1641(v \mathrm{C}=\mathrm{O})\right)$. 